\title{
A CRÍTICA HERMENÊUTICA DO DIREITO COMO GARANTIA A DEMOCRACIA E RESPEITO A CONSTITUIÇÃO FRENTE AO ATIVISMO JUDICIAL
}

\author{
Lívia Copelli Copatti ${ }^{1}$
}

\section{Resumo}

A Constituição Federal de 1988 é marco essencial na garantia de direitos e a respectiva concretização através dos instrumentos elencados no próprio texto constitucional, servindo também como fundamento do Estado Democrático de Direito. Em razão da necessidade constante de efetivar os direitos previstos, o Poder Judiciário acaba tornando-se um dos vetores para tanto e, por vezes, acaba extrapolando os limites em que poderia manifestar-se. Neste ponto reside a presente discussão, qual seja, a problemática do respeito à democracia frente ao ativismo judicial. Para o desenvolvimento do estudo é usado o método dedutivo. Inicialmente apresenta-se uma abordagem histórica acerca da democracia e sua relação com a jurisdição constitucional. Na sequência, constrói-se um apanhado conceitual sobre o ativismo judicial e os fatores que o envolvem, lançando-se a pergunta: "como estabelecer controles à interpretação do direito e evitar que os juízes se apossem da legislação democraticamente construída?". Para responder tal questionamento e atender à problemática proposta, utiliza-se da análise da Teoria da Crítica Hermenêutica do Direito, produzida por Lenio Streck, podendo-se afinal, concluir que ela surge como novo paradigma na interpretação do direito, respeitando a democracia e mostrando a superação do ativismo judicial, em especial, pela construção de uma resposta adequada à Constituição.

Palavras-chave: Ativismo judicial; democracia; crítica hermenêutica do direito.

\section{INTRODUÇÃO}

A Constituição Federal de 1988 surgiu trazendo novas perspectivas para a Nação, instituindo o Estado Democrático de Direito como uma conquista para a sociedade brasileira e para a concretização de direitos dos cidadãos. Com o texto constitucional instituiu-se um regime democrático de governo, em especial pela representatividade e pela participação social em processos decisórios políticos.

Houve um rompimento de paradigmas de modelos anteriores que concediam direitos parciais aos cidadãos já que conforme o contexto político, social ou econômico, a gama de direitos era variada, ou seja, direitos civis (individuais), sociais ou políticos ou ainda, direcionada para categorias específicas de indivíduos, como a escolha de representante pelo voto censitário.

\footnotetext{
${ }^{1}$ Doutoranda em Direito pela Universidade Estácio de Sá - UNESA/RS. Docente da Escola de Direito da Faculdade Meridional IMED.E-mail: livia_dto@yahoo.com.br
} 
Assim, o texto constitucional acaba rememorando que o cidadão tem direitos das mais variadas ordens como individuais, sociais e políticos e traça ainda alguns instrumentos para a concretização daqueles, sendo que o mais destacado é o Poder Judiciário.

Com o constitucionalismo e a democratização, também surge a discussão sobre a presença mais incisiva do Poder Judiciário em questões que demandam uma decisão conforme a legislação e que garanta os direitos do cidadão, assegurados constitucionalmente mas que por vezes, não são cumpridos.

Acontece que, nem sempre, a decisão tomada pelo julgador está fixada no paradigma democrático e constitucional, extrapolando os limites que o próprio constituinte estabeleceu o que faz com que a atuação do Poder Judiciário seja além do esperado, incidindo naquilo que se chama de ativismo judicial e violando a Constituição e a Democracia.

Então, o presente estudo surge com o intuito de discutir o ativismo judicial na suposta concretização de direitos fundamentais e como isto é visto frente à Constituição Federal e à Democracia brasileira, propondo-se a superação de tal paradigma ativista com a utilização, principalmente, das contribuições da Teoria Hermenêutica do Direito a partir dos escritos de Lenio Streck.

\section{APORTES TEÓRICOS SOBRE A DEMOCRACIA}

A origem do Estado é tema de estudos e debates constantes. De fato, o que se sabe é que o Estado está vinculado ao poder e à força. A passagem do Estado de Natureza para o Estado Civil representa a concessão de poderes dos indivíduos ao soberano, para que esse lhe garanta direitos presentes no Estado de Natureza.

O Estado moderno surge pelo desgaste da sociedade política medieval, trazendo em si as características do território, do povo e do governo, tendo sido o Estado Absolutista a sua primeira versão, com prevalência do comando absoluto do monarca como um representante divino. A transição para o Estado Liberal deve-se, principalmente, pelo interesse da burguesia em ter também o poder político, além do poder econômico anteriormente conquistado. Neste período houve a limitação da autoridade com o sufrágio e a representação, prosperando a consolidação de direitos humanos e liberdades dos indivíduos. (STRECK; BOLZAN DE MORAIS, 2012, p. 39-56)

O poder, como destaca Barzotto (2007, p. 13), era de competência jurídica e vinculado à lei, surgindo, então, o positivismo sustentado pela ideia de que todo o direito é um conjunto de normas que decorrem de uma ação humana, dispostas de forma hierárquica.

As primeiras iniciativas para superação da concepção liberal de Estado, da mínima intervenção, e pela busca de um Estado mais voltado para as questões sociais foi o marco para o surgimento do modelo de Estado de Bem - Estar Social ou Welfare State, possibilitando a intervenção na vida social. 
Avançando nos modelos estatais surge o Estado de Direito em meados do século XIX, cujo objetivo central era limitar o poder estatal pelo Direito, apresentando-se assim, pela hierarquia legal e também, de direitos fundamentais inerentes ao seu contexto histórico, passando por três fases: liberal, social e democrático. (STRECK; BOLZAN DE MORAIS, 2012, p. 92-94)

A primeira fase é inerente ao nascedouro do Estado de Direito e sua vinculação ao liberalismo, com o marco da legalidade, da divisão de poderes e resguardo de direitos individuais. A segunda fase traduz-se pela inclusão de direitos sociais e pela exigência de prestação positiva do Estado, superando a visão de legalidade liberal de limitação estatal pela legalidade como instrumento de ação. Por fim, ao lado das fases anteriores, a fase democrática surge da busca pela igualdade, ainda associada à legalidade, e também pela necessidade de transformação da realidade, especialmente, possibilitando a participação pública na sociedade. (STRECK; BOLZAN DE MORAIS, 2012, p. 94-106)

A evolução de modelos estatais possibilitou o alcance do Estado Democrático de Direito e, assim, a abordagem da democracia pode ser feita dependendo das concepções adotadas e da época em que ocorreu, possibilitando verificar que, conforme o período histórico, novos conceitos e demandas surgiam, tendo fundamental importância para o caráter democrático de Estado e sociedade.

A análise democrática na Grécia antiga passa pelo conceito original do termo "democracia”, enquanto governo do povo, conceito este adotado pela teoria política ocidental. A distinção existente entre os termos clássicos "governo do povo" e "governo para o povo" é um dos fortes argumentos para aqueles que veem a autocracia como melhor forma de governo que a democracia.

Conforme ressaltado anteriormente, típico dos séculos XVII e XVIII, o Estado Absolutista fortaleceu o rei e os Estados nacionais, sendo a autocracia (monarquia) a forma de governo adotada. O século XIX trouxe a marca dos ideais liberais, representando a busca pela superação da doutrina absolutista de governo. Com o Estado moderno, instituiu-se uma democracia liberal fundada sobre a representatividade eleitoral, tendo havido a limitação da autoridade do governo em contrapartida à ampliação da liberdade do indivíduo e dos direitos individuais, dissociando-se inclusive, o político do econômico.

Desta forma, o povo estaria impossibilitado de exercer o seu poder de maneira direta, escolhendo então, representantes que, como mandatários seus, exerceriam o poder que pertenceria ao próprio povo. Esta é a democracia representativa liberal deixando explícito "[...] que as deliberações coletivas, isto é, as deliberações que dizem respeito à coletividade inteira, são tomadas não diretamente por aqueles que dela fazem parte, mas por pessoas eleitas para esta finalidade", nas palavras de Bobbio (2000, p. 56).

Haveria assim, apenas um centro de poder decisório que, focado no representante do povo, deveria perseguir os interesses da coletividade e da nação. O modelo da democracia moderna seria assim, um modelo 
centrípeto $^{2}$ e onde a soberania ganhava forças, pelo caráter de escolha do representante, que passava a ser representante da nação e não do eleitor em particular.

E assim sendo, iniciou-se a democratização nos países que estavam experimentando o Estado representativo, principalmente através do sufrágio universal, estendendo o voto para homens e mulheres e sem distinção econômica, possibilitando inclusive, a formação de partidos de massa, interessados em competitividade e não em representatividade - em sua maioria.

A democracia representativa dá sinais de crise quando necessita de uma democracia de baixa intensidade mantendo o distanciamento da população dos processos decisórios e da plena participação política. Os questionamentos quanto à sua eficiência são constantes, principalmente quando o governante representativo passa a não dar mais conta de todas as demandas que the são apresentadas, não conseguindo responder de forma exclusiva pela legitimidade do poder político.

E isto decorre de uma razão simples: os governos democráticos foram previstos e idealizados para uma sociedade menos complexa da que se tem apresentado desde meados do Século XX e início do Século XXI e que, em face da burocracia que se instalou e do aumento significativo das demandas, tornaram-se governos sobrecarregados, lentos e seletivos, precisando escolher qual demanda atender antes, fazendo com que haja problemas para a consecução da democracia representativa e a efetividade nos direitos que a sociedade deseja.

Não obstante, com a ampliação do papel do Estado como provedor de direitos, os beneficiários mantiveram-se distanciados das decisões sobre as alternativas de serviços públicos, sendo requisitados tão somente para o exercício do voto como simples exercício de direito político.

Tendo em vista não mais suportar a contento a demanda proposta, a democracia moderna abre-se para novas formas, principalmente para a distribuição de poder para outros centros, tornando-se assim, uma democracia centrífuga, pressupondo participação do indivíduo no processo decisório político, fazendo "transcender a noção obscura, abstrata e irreal de povo nos sistemas representativos" (BONAVIDES, 2003, p. 27), gerando interação do cidadão com a gestão dos interesses da coletividade, o que não significa que a democracia direta estaria por substituir a democracia representativa porque "nada ameaça mais matar a democracia que o excesso de democracia”. (BOBBIO, 2000, p.39, 56)

Mas, a abertura democrática propugnada não é o que se tem visto na realidade brasileira, distanciando-se inclusive das mobilizações sociais que decidiram voltar à rua para protestar mas sem um foco específico. Rebelde sem causa $?^{3}$ Não há, assim, pelo processo de participação social o atendimento das demandas e expectativas

\footnotetext{
${ }^{2}$ Neste sentido ver: BOBBIO, Norberto. O futuro da democracia. 7 ed. Rio de Janeiro: Paz e Terra, 2000, p. 36 e ROCHA, Luiz Alberto Gurjão Sampaio. Estado, democracia e globalização. Rio de Janeiro: Forense, 2008, p. 190.

${ }^{3}$ Ver o texto O velho travestido de novo e o moralismo do Faustão de autoria de Lenio Luiz Streck, disponível no site do Consultor Jurídico, endereço http://www.conjur.com.br/2013-jun-27/senso-incomum-velho-travestido-moralismo-faustao, em que se coloca uma reflexão sobre as mobilizações sociais ocorridas no Brasil em meados de 2013.
} 
sociais como é a proposta constitucional.

A democracia - representativa ou participativa - é um processo e não um resultado, estando por isso, em permanente conflito com as forças que desejam manter os seus interesses acima dos interesses do bem comum, gerando muitas vezes, acomodação da sociedade, ausência de representatividade e descrédito com os resultados, agravando a situação política e social.

Streck e Bolzan de Morais (2012, p.126) ressaltam que o processo democrático deve ter uma reinvenção temporal para que não se acabe com a democracia, que não é um modelo exato e completo, uma vez que "sente-se a democracia como um espaço polifônico onde não há lugar para o estabelecimento de um modelo acabado de ser-estar no mundo, ela vai de encontro a uma história fixada definitivamente”.

Neste contexto, a Constituição Federal de 1988 assegura os direitos sociais e individuais, a liberdade, a segurança, o bem-estar, o desenvolvimento, a igualdade e a justiça, sendo estes, valores dispostos no Preâmbulo da Carta Constitucional e garante mecanismos para concretizá-los, mas sob o viés da democracia representativa e da democracia participativa, tais mecanismos não têm sido utilizados a contento, gerando assim, o déficit nos direitos fundamentais dos cidadãos.

Assume relevância o destaque dado por Sarlet (2012, p. 66) sobre a inovação constitucional ao firmar os direitos fundamentais como base da Constituição, pois trazem a ideia de "parâmetro hermenêutico e valores superiores da ordem constitucional e jurídica” estando situados logo no início do texto constitucional, servindo efetivamente como diretriz para todas as situações envolvendo os indivíduos.

Mas, a simples posição dos direitos fundamentais não basta para sua concretização e, sobre a necessidade de efetivar os direitos previstos na Constituição, novamente resta importante trazer o que expõem Streck e Bolzan de Morais (2012, p. 106), pois referem que o Estado Democrático de Direito teve seu nascimento no constitucionalismo do pós-guerra e que isso traz a noção de uma Constituição compromissória e dirigente, relacionada às especificidades históricas de cada Estado nacional, não sendo apenas instrumento de governo, mas o norte para direitos, programas e fins do Estado e sociedade.

O contexto constitucional brasileiro traz a característica de dirigente e compromissório, sendo que na discussão sobre a "morte” da Constituição dirigente Bercovici (2008, p. 159) sustenta esta:

[...] enquanto projeto emancipatório, que inclui expressamente no texto constitucional as tarefas que o povo brasileiro entende como absolutamente necessárias para a superação do subdesenvolvimento e conclusão da construção da Nação, e que não foram concluídas. Enquanto projeto nacional e como denúncia desta não realização dos anseios da soberania popular no Brasil, ainda faz sentido falar em constituição dirigente.

Em países de modernidade tardia como o Brasil, a teoria da Constituição deve estar adequada aos aspectos e características essenciais do Estado Democrático de Direito, sob pena de estar se adaptando conceitos e teorias que não podem ser aplicadas à determinada realidade. 
Por isso, Streck (2002, p. 113) destaca que a posição de Canotilho, ao dizer que a Constituição dirigente está morta se houver um normativismo revolucionário e que por si só pode operar transformações emancipatórias, em nada enfraquece a noção de Constituição dirigente, pois permanece a noção de que esta é "a vinculação do legislador aos ditames da materialidade da Constituição, pela exata razão de que, nesse contexto, o Direito continua a ser um instrumento de implementação de políticas públicas".

A Constituição Dirigente é a prospecção para o futuro, não simplesmente a sua existência formal; é a direção para a atuação estatal e o meio para sua exigência, vinculando o legislador e os particulares. Isto significa dizer que algo ainda não está cumprido - ou pronto - e que demanda uma série de ações em prol do desenvolvimento, dos direitos fundamentais e sociais e da democracia.

O destaque para a vinculação entre Constituição compromissória e dirigente é dado por Oliveira (2010, p. 39) quando diz que "a diretividade constitucional é decorrência do pacto político firmado, é a concepção de Estado e de sociedade vitoriosa entre outras postas em disputa no momento constituinte", não se podendo perder de vista que o dirigismo constitucional é produto do compromisso constitucional e democraticamente formulado.

Portanto, a Constituição dirigente do Estado Democrático de Direito é condição de possibilidade para o cumprimento das promessas da modernidade não cumpridas pelo Estado Social e nem pensadas no Estado Liberal, sendo o sustentáculo para a democracia.

A ineficiência na questão das políticas públicas para realização dos direitos dos cidadãos e a falha no exercício da democracia representativa e da democracia participativa são alguns dos fatores que acabam levando o cidadão a procurar outro centro decisório para cumprir aquelas promessas da modernidade e que o poder político não tem conseguido alcançar pelo sistema atual, chegando sua insatisfação ao Poder Judiciário.

Marca importante no que diz respeito à Constituição dirigente e à realização dos direitos fundamentais é a previsão do art. $5^{\circ}, \$ 1^{\circ}$ da Constituição Federal sobre a aplicabilidade imediata das normas definidoras dos direitos e garantias fundamentais ${ }^{4}$.

Neste ínterim, a Constituição Federal garante o "acesso ao Poder Judiciário" uma vez que refere no artigo 5o, inciso XXXV que "a lei não excluirá da apreciação do Poder Judiciário lesão ou ameaça a direito". Tal dispositivo caracteriza o acesso à justiça, que no caso, é utilizado como sinônimo de Poder Judiciário ou ainda, chamado de princípio da inafastabilidade do controle jurisdicional ou direito de ação, contemplando assim, direitos individuais, difusos e coletivos a serem atendidos pelo Poder Judiciário.

A proteção constitucional aos direitos fundamentais é complementada pelo rol de garantias judiciais constitucionais postas à disposição do cidadão, podendo-se citar o habeas corpus, o habeas data, o mandado de 
segurança e o mandado de injunção, todos com previsão expressa no art. 5, LXIX, LXX, LXXI e LXXII.

Além dessas garantias, também podem ser lembradas a ação direta de inconstitucionalidade, a ação declaratória de constitucionalidade, a ação direta de inconstitucionalidade por omissão, a arguição de descumprimento de preceito fundamental, a ação popular e a ação civil pública que têm sido utilizadas como controle da constitucionalidade das leis e, por vezes, servindo para realizar direitos.

Mas, se existem tantos instrumentos para efetivar os direitos garantidos constitucionalmente, é exatamente "a confissão de que as promessas da realização da função social do Estado não foram (ainda) cumpridas" (STRECK, $2011^{\text {a }}$. Aqui, insere-se, portanto, a discussão sobre a jurisdição constitucional e o seu fundamento na realização dos direitos fundamentais.

O Estado Democrático de Direito aproxima as ideias de constitucionalismo, com destaque para limites ao poder e supremacia legal e, de democracia, marcada pela soberania popular. Embora pareçam antagônicos, constitucionalismo e democracia complementam-se e tornam-se fundamentais reciprocamente no momento em que existe a necessidade de harmonização da Constituição com as deliberações sociais e políticas, devendo-se garantir direitos, a participação popular e preservar as minorias de violações em nome de um poder constituído por maiorias.

Isto significa dizer que a jurisdição constitucional é compatível com a democracia na imposição de limites aos desígnios majoritários, reforçando as condições normativas da democracia, sendo que ao legislador democrático cabe a formulação de políticas públicas e ao Poder Judiciário a guarda da Constituição e os direitos nela reconhecidos, tendo-se como desafio imposto à jurisdição constitucional a conciliação entre proteção de direitos e democracia. (MENEDES, 2013)

Separar e contemporaneamente harmonizar os poderes diz respeito ao controle existente entre Executivo, Legislativo e Judiciário e também à necessidade de que não haja abuso de poderes constituídos popularmente (Executivo e Legislativo) sobre os cidadãos que os elegeram - e também que não o fizeram -, como se isso estivesse justificado pelo simples fato de estar nos cargos pela maioria, o que significaria uma violação frontal à democracia.

É assim que a jurisdição constitucional também se revela necessária para evitar e combater os abusos da maioria parlamentar e assegurar os direitos das minorias, como refere Agra (2012, p. 652)5 e Tavares (1988). Mas, abordar justiça constitucional significa analisar e compreender o sistema de freios e contrapesos ou checks and balances sob uma nova postura, não significando apenas um mecanismo de controle, mas também, traduzindo-se na possibilidade de que direitos sejam efetivados por uma atuação mais ativa, o que não implica a negação ou

\footnotetext{
${ }^{4}$ A respeito do problema da eficácia dos direitos fundamentais, interessante o estudo desenvolvido por Ingo Wolfang Sarlet na análise da aplicabilidade imediata do art. 5\%, \$1º da Constituição Federal. (SARLET, 2012, p. 261 - 274).
} 
minimização da separação de poderes, como advém da análise de Ferreira Filho (2013, p. 119) e nem deve implicar em ativismo judicial.

Nesse contexto, não servindo apenas para controle de constitucionalidade das leis, tem-se uma jurisdição constitucional com "missão de concretizar os mandamentos contidos na Constituição, fazendo com que as estruturas normativas abstratas possam normatizar a realidade fática" (AGRA, 2012, p. 646), de forma que, com isto, possa ser compreendida como uma garantia para os direitos fundamentais dispostos constitucionalmente.

Ressalta-se que se inicialmente a jurisdição constitucional teve uma posição de autocontenção, não contrariando a vontade legislativa e por isto não conflitando com a democracia, posteriormente o Judiciário assumiu um novo papel, apresentando-se ativamente como garantidor de direitos individuais e coletivos, decorrente da democratização da justiça.

Assim, o Poder Judiciário acaba ganhando contornos mais presentes e deixa a sua posição passiva de aplicador de lei, "para assumir uma postura central e ativa diante de um contexto de descompasso entre o projeto político-constitucional e o contexto socioeconômico" (STRECK, 2009, p. 28) para a concretização da Constituição e a transformação social.

Acontece que a instabilidade representativa e democrática do parlamento e do próprio Poder Executivo, conforme já analisado, acaba repassando ao Poder Judiciário a responsabilidade originária daqueles que contam com o apoio da maioria cidadã. Isto acarreta a judicialização da política ou a transferência do poder decisório do Poder Executivo e do Poder Legislativo para os juízes e tribunais, não podendo ser confundida com o ativismo judicial.

Sabino (2013) destaca que os poderes políticos majoritários - Executivo e Legislativo - exaram uma decisão política quando da implementação de políticas públicas e que invariavelmente não atendem a todos, $o$ que acaba sendo agravadas por falhas, insuficiências de recursos e situações emergenciais. Então, insere-se o Poder Judiciário na questão política, pois em não sendo assim, o Estado não teria como garantir direitos e assegurar o bem comum, o que não significa que tal atuação será realizada sem limites.

Também, destacando a importância da atuação e, nesse passo da limitação do Poder Judiciário, está Cittadino (2012, p. 19), para quem "é fundamental que o seu atual protagonismo seja compatível com as bases do constitucionalismo democrático", reforçando a necessidade de que não sejam extrapolados os limites entre aquilo que se entende por judicialização da política e alcançando o ativismo judicial.

Streck (2013) refere que quando o Poder Judiciário passa a ter um papel de destaque frente aos demais poderes e uma maior atuação do que em tempos passados, intrinsecamente a discussão sobre a limitação desta atuação receberá atenção e a preocupação das discussões públicas, pois o que interessa não é "o quanto de

${ }^{5} \mathrm{O}$ autor entende que a função da jurisdição constitucional, quando a vontade da maioria tentar ou suprimir os direitos mínimos vol.09, nº. 04, Rio de Janeiro, 2016. pp. 2421-2449 2428 
judicialização", mas “como as questões judicializadas" devem ser decididas.

E assim a judicialização da política é entendida por Tassinari (2013, p. 32) como uma questão social, que não depende da vontade do órgão judicante, mas de uma série de fatores que iniciam na ineficiência do Estado na implementação de direitos e acabam no Poder Judiciário e no aumento da litigiosidade, dependendo a sua diminuição de medidas que envolvam todos os poderes que, necessariamente, estão envolvidos.

Na medida em que a vinculação do Poder Judiciário é constitucional, sua atuação não pode ser ilimitada e desarrazoada, mas vinculada ao princípio democrático de respeito à soberania popular e, sendo também, assim, possível a concretização dos direitos. Embora isto seja o desejável, por vezes ocorre uma extrapolação de poderes do Poder Judiciário em suas decisões, com intervenção em outros campos, não jurídicos, o que acaba incidindo em ativismo judicial, objeto das reflexões que seguem.

\section{O ATIVISMO JUDICIAL E SUA VERSÃO BRASILEIRA}

Sob o viés constitucional a todos é garantido o direito de provocar o Poder Judiciário em caso de lesão ou ameaça de direito, sendo imperiosa uma solução do conflito. Isto é resultado dos déficits de direitos fundamentais, que acabam fazendo com que os poderes instituídos sejam pressionados a responderem estas questões e acarretando ao Poder Judiciário o aumento de demandas.

Com a possibilidade de provocar o Poder Judiciário para uma solução ao caso concreto, não raramente acaba a decisão sendo fruto de um ativismo judicial - diferente de judicialização da política, como ressaltado, sendo necessário destacar o construto histórico desenvolvido por Streck, contextualizando positivismos e póspositivismos, partindo do positivismo como lei, em especial, Códigos Civis.

Antes da codificação, o que não pudesse ser resolvido pelo direito comum o seria pelos critérios que adviessem dos estudiosos do direito romano, os glosadores (STRECK, 2012, p. 31-32). Mas, como o que estava escrito nos Códigos não alcançava a realidade, surgiu a necessidade de controlar a interpretação do direito e excluir os elementos metafísicos do modo positivista, aparecendo assim, a Escola da Exegese e a Jurisprudência dos Conceitos, dando origem ao positivismo exegético e ao positivismo normativista.

O positivismo primitivo, exegético ou legalista não permitia interpretações, fundava-se na separação entre direito e moral e a "rigorosa conexão lógica dos signos" era suficiente para resolver a interpretação do direito; o positivismo normativista aparece como aperfeiçoamento do rigor proposto anteriormente, tendo Kelsen sido o seu expoente, com a constatação de que o problema da interpretação do direito era semântico - cinde-se interpretação como ato de vontade e interpretação como ato de conhecimento, sendo que o primeiro, em sua 
aplicação, produz normas (semântica), em sentido discricionário e o segundo, produz proposições que se relacionam de maneira lógico-formal (sintática). (STRECK, 2012, p. 31-32)

Ressalta-se que em toda a tentativa de superação do positivismo primitivo construíram-se teses que passaram da razão para a vontade, em especial com o movimento do direito livre, o realismo norte-americano, a Jurisprudência dos Interesses, e a Jurisprudência dos Valores. As duas últimas têm maior expressão na construção daquilo que se chama de neoconstitucionalismo, já que para a jurisprudência dos interesses, o conflito era resolvido pela ponderação dos interesses e para a jurisprudência dos valores, o conflito deveria ser resolvido para além daquilo que o direito escrito trazia que eram os valores. (STRECK, 201 la, p. 122-123)

A partir daí, o direito passou a ser visto como objeto analisado por critérios metafísicos, mas que em situações específicas, principalmente pela utilização da ponderação acaba sendo produto do sujeito do conhecimento, o sujeito solipsista, que acaba decidindo conforme sua consciência, sem fundamento legal e nem principiológico. É o ápice do sujeito-objeto.

Nesse contexto, insere-se o pós-positivismo ou neoconstitucionalismo abordado de diferentes formas pelos autores e que é de importante análise para a compreensão do ativismo. Bulos $(2010$, p. 79, 86) refere ser exatamente o mesmo que o constitucionalismo contemporâneo, recebendo influências da Filosofia do Direito, sendo característica o destaque aos direitos e garantias fundamentais como resposta às angústias sociais, entre outras. $\mathrm{O}$ autor critica o neoconstitucionalismo pela deturpação feita com institutos como os princípios, quando diz que "supervalorizaram tanto as normas-princípio, que elas passaram a ser mais importantes do que as normas em geral. E como tudo virou princípio, muitos juízes deixam de aplicar as normas jurídicas em nome de ilações $[\ldots]$...

Em contraponto, Streck (2012, p. 35-37) refere que o neoconstitucionalismo não tem o mesmo sentido de constitucionalismo contemporâneo ${ }^{6}$, já que aquele está vinculado à ideia de discricionariedade judicial e decorre da possibilidade de acionar o Poder Judiciário para concretizar direitos que, até então, restam previstos na Constituição.

É necessário trazer o entendimento de Barroso (2009, p. 344), que tem sido tratado como expoente do constitucionalismo, quando ao tratar do pós-positivismo destaca uma nova percepção e refere o seguinte "Sua marca é a ascensão dos valores, o reconhecimento da normatividade dos princípios e a essencialidade dos direitos

\footnotetext{
6 Streck revê sua posição quanto a aceitação do termo neoconstitucionalismo superando-o por Constitucionalismo Contemporâneo, justificando que a adoção do neoconstitucionalismo significaria estar aceitando a recepção da Jurisprudência dos Valores, da teoria da argumentação e do ativismo judicial norte-americano no Brasil. Assim, refere que o neoconstitucionalismo, como entendido na realidade, não passa de uma simples superação do paleojuspositivismo ou positivismo primitivo em que tudo estava na lei, passando a uma abertura para interpretações discricionárias e solipsistas, de forma que isto não pode ser aceito na realidade nacional. Portanto, o termo Constitucionalismo Contemporâneo significa uma melhor adequação à Critica Hermenêutica do Direito, pois condiz com o redimensionamento na práxis político-jurídica (plano da teoria do Estado e da vol.09, nº. 04, Rio de Janeiro, 2016. pp. 2421-2449 2430
} 
fundamentais [...] nova hermenêutica e a ponderação de interesses são componentes dessa reelaboração teórica, filosófica e prática [...]".

A compreensão dada por aqueles denominados pós-positivistas nada mais é do que deixar os critérios para decidir casos difíceis, à escolha dos juízes. O contraponto novamente feito por Streck (2012, p. 64), no que diz respeito ao pós-positivismo, merece destaque, devendo ser "compreendido, nesse contexto, no interior do paradigma do Estado Democrático de Direito instituído pelo constitucionalismo compromissório e transformador social [...]”. É a isto que o autor chama de Constitucionalismo Contemporâneo.

Ao fazer a crítica sobre o reconhecimento do neoconstitucionalismo frente à democracia, Nojiri (2012, p. 305) trata da problemática da concepção equivocada do termo nos dias atuais, no seguinte sentido:

Para o neoconstitucionalismo, portanto, as normas constitucionais constituem-se em valores (princípios) objetivos que devem ser descobertos e aplicados. Ainda segundo essa forma de entender o direito, são os juízes os principais protagonistas do processo de concretização das normas constitucionais, uma vez que são eles os detentores do método (racional) adequado de aplicação dessas normas. Esse método (argumentativo) seria o da ponderação de valores. No discurso neoconstitucionalista a crença nas capacidades de decisão do juiz aumenta na mesma medida em que diminui a confiança no legislador democrático.

Para Sarmento (2009), o neoconstitucionalismo vai ceder espaço a visões favoráveis ao ativismo judicial, à ponderação nos casos difíceis, ao papel criativo da jurisprudência, à abertura do direito para o debate moral.

E assim, Sarmento (2009, p.20-21) deixa claro o foco do neoconstitucionalismo no ativismo judicial e no solipsismo do julgador quando refere: "O grande protagonista das teorias neoconstitucionais é o juiz. O direito é analisado, sobretudo a partir de uma perspectiva interna, daquele que participa dos processos que envolvem a sua interpretação e aplicação". E, complementa dizendo: "esta obsessão do Poder Judiciário leva a certa desconsideração do papel desempenhado por outras instituições, como o Poder Legislativo, na interpretação constitucional. [...]”.

Resta clara a posição de Sarmento (2009), reconhecendo expressamente o ativismo judicial como uma das faces do neoconstitucionalismo, o que também é reconhecido por Streck e Nojiri, muito embora para estes autores o ativismo judicial, na forma como apresentado, com a possibilidade de discricionariedades, não é benéfico para o Estado Democrático de Direito, o que para Sarmento, afigura-se a ampla legitimidade do ativismo em favor dos valores constitucionais.

Também no mesmo sentido de Sarmento, insta referir o que Barroso (2013) destaca sobre o neoconstitucionalismo, reforçando a discricionariedade ou ativismo, uma vez que envolve uma série de elementos característicos da discricionariedade.

Trata-se de falar de cláusulas gerais, princípios, colisões de normas constitucionais que leva à ponderação e argumentação, entendendo o neoconstitucionalismo sob três marcos: o histórico, com a consolidação do 
Estado constitucional de direito no final do século XX; o filosófico, com o pós-positivismo, o papel central alcançado pelos direitos fundamentais e a reaproximação entre Direito e ética e; o teórico, referente à força normativa da Constituição, a expansão da jurisdição constitucional e uma nova dogmática da interpretação constitucional.(BARROSO, 2013)

Das ideias desenvolvidas por Barroso, não é difícil identificar uma postura que, embora estabeleça a contenção da discricionariedade judicial, o faz utilizando a ponderação de valores e interesses, voltando à ideia de escolha, de decisão conforme a própria consciência do juiz.

Ferrajoli (2012, p. 15-17) destaca que a expressão neoconstitucionalismo está carregada de ambiguidade, inicialmente porque o termo "constitucionalismo" acaba sendo parte do léxico político e não jurídico, o que impede a transformação de paradigma e intervenção na estrutura do direito positivo. E diz mais: neoconstitucionalismo é sinônimo de Estado Liberal de Direito; está identificado com a concepção jusnaturalista do constitucionalismo e, o positivismo jurídico assume sentido que não possibilita a contraposição ao neoconstitucionalismo.

Assim, para superar a oposição entre neoconstitucionalismo e positivismo jurídico, Ferrajoli (2012) propõe uma terminologia diversa, ou seja, constitucionalismo jurídico, o qual se subdivide em constitucionalismo argumentativo ou principialista e o constitucionalismo garantista, sintetizados por Trindade (2012, p. 101-102).7

Nessa revisão terminológica de Ferrajoli, o garantismo assume um viés interessante, já que proposto como um novo paradigma jurídico e democrático, rompendo com o positivismo exegético, necessitando do constitucionalismo para que possa ser realidade e cumprir com os direitos fundamentais, sendo, portanto, o oposto do neoconstitucionalismo.

Buscando apresentar uma síntese de ideias neoconstitucionalistas, merece destaque o estudo realizado por Trindade (2012, p. 106-107), que refere três fatores importantes para tal teoria. O primeiro diz respeito ao surgimento do Estado Constitucional de Direito que acaba por justificar a constitucionalização dos ordenamentos jurídicos, sendo que o referido Estado acaba sendo o ponto inicial para a pretensão de superar o paleojuspositivismo ou positivismo primevo.

O segundo fator importante diz respeito à inconsistência e incongruência de diversos autores, sendo citados Alexy, Dworkin, Nino e García Figueroa. Então, faz sentido a proposta de Ferrajoli de substituir o termo neoconstitucionalismo por constitucionalismo argumentativo, em razão de que os adeptos àquele centralizam

teoria da interpretação).

${ }^{7} \mathrm{O}$ constitucionalismo argumentativo ou principialista é caracterizado assim: a relação entre direito e moral resulta em um constitucionalismo ético; grande parte das normas constitucionais configura-se como princípios e aplica-se nos casos difíceis; argumentação jurídica e ponderação. De outra parte, o constitucionalismo garantista tem como características: superação do paleojuspositivismo (modelo ou sistema jurídico); aborda tensão entre dever ser e ser do direito (teoria do direito); consiste em teoria da democracia ancorada no Estado Constitucional de Direito (filosofia e teoria política). 
suas ideias na teoria da argumentação jurídica. (TRINDADE ,2012, p.107)

O terceiro fator está relacionado intrinsecamente com o assunto foco deste trabalho, que é o protagonismo judicial, ou seja, a assunção, pelos juízes, de papel central no Estado Constitucional de Direito, decorrente da expansão do Poder Judiciário e do fenômeno da judicialização da política, quando se supera o passivismo pelo ativismo judicial. (TRINDADE, 2012, p.108-109)

Como visto, uma das faces do neoconstitucionalismo é o ativismo judicial. De fato, a primeira ideia de ativismo veio dos Estados Unidos, embora diferente daquilo que se entende como ativismo no Brasil. Streck (2002, p. 262) assegura, com suporte em Fioravanti, que o poder constituinte do povo americano serviu para entender a Constituição como lei suprema e estabelecer pareceres que dificultam sua revisão, o que, juntamente com a Bill of Rights desenvolveu o controle difuso de constitucionalidade norte-americano.

Apesar de não estar reconhecida explicitamente na Constituição Americana de 1787, foi a partir dela que o judicial review foi ocupando espaço, em especial, com o julgamento do caso Marbury v. Madison, embora, como já dito, sem qualquer previsão constitucional sobre o poder de revisão da legislação pelos Tribunais. (STRECK, 2002, p.264)

E sobre o que diz respeito ao controle de constitucionalidade, cabe mencionar novamente Streck, quando destaca que a Suprema Corte Americana pode ser descrita em três fases, quais sejam: a primeira tradicional, no período de 1798 a fins do século XIX - em que a Constituição era inteligível e substantiva ao mesmo tempo, sendo o controle judicial visava a supremacia da regra constitucional; a segunda - conservadora, de fins do século XIX a 1937 - interpretando a Constituição em sentido conservador da ordem liberal capitalista e manifestando autoridade em face do Poder Legislativo.

Nesta segunda fase, a marca ocorre em 1905, com o caso chamado Lochner v. New York em que a decisão da Corte norte-americana adotou duas posturas, uma progressista, interferindo na política legislativa e outra, conservadora, pela não intervenção na esfera privada dos cidadãos. (TASSIRANI, 2013, p. 24)

A terceira fase - legislativa, pós 1937 - instaurou uma interpretação do poder judicial como legislativo, com análise da Common Law, com a resolução dos casos baseando-se nos precedentes judiciais quando ausente a lei, modificando as regras dos precedentes conforme o caso, ou seja, legislando. O grande marco para esta fase foi o julgamento, em 1954, do caso Brown v. Board of Education, tendo ainda, como característica, a doutrina Warren ou Tribunal Warren. (STRECK, 2002, p. 268)

Ainda, conforme Teixeira (2013), o judicial activism entrou no léxico político e popular, quando o historiador Arthur Schlesinger Jr publicou matéria na Revista Fortune chamada The Supreme Court:1947, e chamou alguns juízes de ativistas judiciais e outros de campeões do autocomedimento. Mas, segundo Teixeira, a crítica realizada por Schlesinger possui imprecisão terminológica da expressão judicial activism e indefinição sobre ser algo positivo ou negativo, embora, de outra parte, deixe claro os conflitos do ativismo judicial: 
Juízes não eleitos vs. leis democraticamente aprovadas; decisões orientadas politicamente vs. decisões orientadas juridicamente; uso criativo do precedente vs. uso estrito do precedente; supremacia da vontade popular vs. direitos humanos; política vs. direito.

Assim, verifica-se que a origem do ativismo judicial e o seu inicial debate aconteceu nos Estados Unidos e, da forma como trazido para o Brasil, tem sido objeto uma série de entendimentos contrários e contraditórios.

Neste sentido, face às imprecisões de sentido e terminológicas, Trindade (2012, p. 111), apoiado em Marshall, enumera sete tipos de ativismo, quais sejam: contramajoritário, não originalista, de precedentes, jurisdicional, criativo, remediador, partisan. Dos tipos de ativismo expostos, todos tem relação com o excesso de atuação do Judiciário, ultrapassando os limites democráticos impostos para o exercício do poder.

Ocorre que, o ativismo judicial na forma como tratado e compreendido no Brasil, faz parte daquilo que Streck chama de recepções teóricas equivocadas, uma vez que, com a Constituição novos ideais, novos direitos e novos modos de ver e concretizar direitos eram necessários e, pela carência de respostas a todas as demandas, buscou-se em teorias de outros países o sustentáculo para o direito nacional.

Isto acabou fazendo com que diversas teorias fossem recepcionadas de forma equivocada, sem a necessária crítica e adequabilidade à realidade nacional e, uma das recepções é o ativismo judicial e a consequente aposta no protagonismo dos juízes, que juntamente com a Jurisprudência dos Valores e a ponderação acabam violando o constitucionalismo e o princípio democrático.

A influência da Jurisprudência dos Valores no ativismo judicial brasileiro é bastante presente, decorrente da recepção - equivocada - da teoria aplicada na Alemanha, nos anos seguintes à consagração da lei fundamental alemã. Na verdade, serviu para que o Tribunal pudesse recorrer a critérios decisórios fora da estrutura rígida legal, e "a referência a valores aparece, assim, como mecanismo de "abertura" de uma legalidade extremamente fechada que possibilitara, em alguma medida, o totalitarismo nazista”. (STRECK, 2013b, p. 21)

A Jurisprudência dos Valores tem aquilo que Oliveira (2013) chama de colorido filosófico: “auxiliar o julgador a identificar os valores que subjazem ao direito naquele dado conflito levado à sua apreciação”. E completa: "sua contribuição é conduzir a solução da "criação judicial do Direito" nos casos de lacunas pelos valores que sustentam todo o discurso sobre o Direito”.

Para Cittadino (2002, p.23), a Jurisprudência dos Valores defende a ideia de que a Constituição traduza uma autocompreensão ético-normativa tendo a função de aproximar normas constitucionais da realidade histórica. Assim, está relacionada à filosofia da consciência ou paradigma da subjetividade, podendo ser identificada claramente nas questões relativas ao ativismo, decisionismo e poder discricionário, quando, poderá utilizar-se de cláusulas gerais e conceitos indeterminados para solucionar um caso concreto.

O Poder Judiciário como visto, é chamado para resolver as celeumas dos seus jurisdicionados e, face à recepção equivocada da jurisprudência dos valores, acaba por extrapolar suas funções, pois como refere Trindade (2012, p. 116-117) acaba no "desenvolvimento de um ativismo judicial sui generis - impulsionado pela vol.09, no. 04, Rio de Janeiro, 2016. pp. 2421-2449 
judicialização da política, sob os influxos do neoconstitucionalismo e das teorias da argumentação". E, o resultado é:

[...] a institucionalização de um verdadeiro ativismo judicial às avessas, em que se confere discricionariedade aos juízes, para, nos casos concretos, buscarem em suas consciências uma solução que atenda aos fins de justiça social, autorizando-os tanto à criação do direito quanto ao gerenciamento processual, o que implica uma intervenção indevida tanto na esfera administrativa quanto legislativa.

Alguns autores creditam ao ativismo judicial a importante tarefa de concretizar aquilo que o constituinte desejou, mas pelas insuficiências, principalmente econômicas e sociais, não foi possível tornar realidade acessível a todos. Neste sentido, é que Sadek (2013, p. 18), reconhece ao Judiciário a posição de ator político, destacando que preenche "brechas" do Legislativo e que o protagonismo judicial encontra guarida principalmente pela amplitude dos direitos reconhecidos e dispostos na lei.

E diz mais, que as críticas dispensadas ao ativismo não foram capazes de interromper sua materialização e expansão, razão pela qual se estendeu à maioria dos Estados constitucionais, sendo por isto, na concepção de Sadek (2013, p. 27), necessário ao estágio atual do Estado brasileiro.

Mas, o simples fato de ser praticado como algo "natural", não significa que é a postura correta a ser adotada pelos Tribunais, principalmente quando em confronto com as conquistas de cidadania e democráticas, como questiona Streck (2013b, p. 60):

Porque, depois de uma intensa luta pela democracia e pelos direitos fundamentais, enfim, pelas conquistas civilizatórias nos textos legais-constitucionais, deve(ría)mos continuar a delegar ao juiz a apreciação discricionária nos casos de regras (textos legais) que contenham vagueza e ambiguidades nas hipóteses dos assim denominados hard cases?

Portanto, o Poder Judiciário sai de uma posição quase nula, de um juiz "boca da lei”, responsável apenas por pronunciar os termos da lei e passa a ocupar posição destacada no campo político e institucional, espalhando decisões proferidas por juízes solipsistas, fundamentados em sua própria consciência, com a moral, a política, a economia, entre outros fatores.

Imbricada com o ativismo judicial e a Jurisprudência dos Valores está a ponderação. Com a recepção daquela também foi aceita a tese de que a ordem jurídica é composta de valores constitucionais e que cabe ao intérprete encontrar os interesses ou valores com o auxílio da teoria da argumentação de Robert Alexy e a utilização da ponderação de princípios para resolver os chamados "casos difíceis", de modo que os casos fáceis seriam solucionados com a subsunção.

Em que pese no chamado pós-positivismo, a adoção da ponderação tenha a intenção de substituir a decisão discricionária do juiz, acaba tendo o mesmo sentido, pois existe a continuidade da problemática da delegação ao sujeito para a escolha subjetiva do princípio que acredita melhor se adequar ao caso concreto.

A discussão inicial se dá em razão de algumas decisões emanadas do Tribunal Constitucional Alemão, onde Alexy pretendia desenvolver uma estrutura procedimental para evitar erros da jurisprudência dos valores, o 
fazendo pela ponderação, embora admita que a discricionariedade do julgador seja inevitável. Então, surge o destaque para os princípios como mandados de otimização e abertura para o julgador, já que as regras não podem ser discricionárias, pois operam por subsunção. (OLIVEIRA, 2007, p. 44)

A ligação entre a teoria alexyana ao protagonismo judicial é clara, já que o sujeito da interpretação é o juiz e suas escolhas, pois embora a ponderação tente livrar o direito do positivismo primitivo, o coloca sob o domínio do positivismo pragmaticista, com o sopesamento de princípios, colocando aí a questão: "quem escolhe os princípios a serem ponderados?”. (STRECK, 2011b, p. 9-27)

Nojiri $(2012,294)$ trata da subsunção e da ponderação e refere que esta última passa a falsa ilusão da existência de uma ordem de valores e que o método ponderativo pode revelar a melhor decisão, desde que sejam bem sopesados tais valores. E acrescenta o que defende o neoconstitucionalismo: "uma Constituição material (ou substancial) com valores objetivos que podem ser sopesados de forma a se obter somente decisões racionais, e, portanto, (moralmente) corretas". Mas, como referido pelo autor, o neoconstitucionalismo esqueceu-se de dizer quais os valores e como serão revelados.

Streck (2012, p. 235) observa sobre a diferença entre a hermenêutica e a teoria da argumentação o seguinte:

[...] enquanto a teoria da argumentação compreende os princípios (apenas) como mandados de otimização, portanto, entendendo-os como abertura interpretativa, o que chama à colação, necessariamente, a subjetividade do intérprete (filosofia da consciência), a hermenêutica - como já referido à saciedade - parte da tese de que os princípios introduzem o mundo prático no direito, "fechando" a interpretação, ou seja, diminuindo, ao invés de aumentar, o espaço da discricionariedade do intérprete. [...] primeiro, são incindíveis os atos de interpretação e aplicação (com o que se supera o método) e, segundo, não há diferença estrutural entre hard cases e easy cases.

A forma como são aplicados os princípios, em especial pela ponderação, é chamada por Trindade (2012, p. 118) de máscara da subjetividade, pois dispostos como enunciados performativos disponíveis para que os intérpretes decidam da maneira como bem entenderem, destacando que, nestes casos, os princípios mais invocados são a proporcionalidade e a razoabilidade.

Novamente calha observar o que destaca Streck (2011a, p. 145) com sua percuciente explicação:

[...] é equivocado pensar que os princípios constitucionais representam a positivação dos valores. O Direito é um sistema formado por regras (preceitos) e princípios. Ambos são normas. [...]

A regra não subsiste sem o princípio. Do mesmo modo, não há princípio que possa ser aplicado sem o "atravessamento" de uma regra. A regra não explica; a regra esconde. $\mathrm{O}$ princípio desnuda a capa de sentido imposta pela regra [...]. O princípio é a enunciação do que está enunciado.

Ponderação não é princípio, é regra. A sua utilização pelos tribunais brasileiros acabou por descaracterizar a teoria alexyana, aproximando-se da jurisprudência dos interesses e da jurisprudência dos valores, decorrendo da fábrica de princípios ou, do panprincipiologismo, com a proliferação incontrolada de enunciados para serem aplicados e resolver problemas concretos, distanciando-se da própria legalidade constitucional. vol.09, n. 04, Rio de Janeiro, 2016. pp. 2421-2449 2436 
(STRECK, 2011a, p. 366)

Portanto, a problemática da ponderação insere-se como um dos pontos centrais na discussão do ativismo judicial propalado no Brasil, já que aposta, em razão de sua recepção equivocada, na escolha de um princípio que deverá ser aplicado ao caso, conforme o juiz ou o Tribunal assim o quiserem, em um nítido e prejudicial, resgate da filosofia da consciência.

Em síntese, pode-se dizer com Tassinari (2013, p. 114) que a Jurisprudência dos Valores, a ponderação e o ativismo judicial norte-americano acabam gerando o protagonismo judicial, violando a democracia, pois acaba desvinculando-se da legalidade, com a abertura de espaços para a vontade do intérprete, assumindo o Poder Judiciário uma interferência política.

O juiz não pode simplesmente decidir da forma como quiser ou conforme aquilo que acha correto. Deve decidir com base na Constituição e calcado em princípios constitucionais aplicáveis para a questão, não havendo que se falar em ponderação de princípios e em seus valores pessoais.

E aqui surge o questionamento proposto por Streck (2012, p. 364): "como estabelecer controles à interpretação do direito e evitar que os juízes se assenhorem da legislação democraticamente construída?”.

A secção seguinte buscará responder a tal questionamento a partir da análise da Crítica Hermenêutica do Direito, proposta por Streck, com base na imbricação das teorias de Gadamer e Dworkin.

\section{A CRITICA HERMENEUTICA DO DIREITO: GARANTIA A DEMOCRACIA E RESPEITO A CONSTITUIÇÃO FRENTE AO ATIVISMO JUDICIAL}

De tudo o visto, percebe-se que o advento do texto constitucional - democrático - trouxe ínsita a necessidade de que os direitos fossem respeitados e concretizados, fazendo com que o legislador fosse o promotor disto e que, quando isto não acontecesse, então o juiz ou tribunal pudesse atuar em conformidade com o texto constitucional concretizando o direito postulado.

No plano ideal, tal proposição funciona perfeitamente. Mas, no plano fático, não é exatamente o que se tem visto, onde a busca pela efetivação dos direitos acaba, no mais das vezes, incidindo em decisionismo judicial, isto é, em decisão discricionária e baseada em modelos interpretativos inconsistentes ou inaplicáveis na realidade brasileira. Este é o ativismo judicial à brasileira.

Decorrente da necessidade de superar o decisionismo e o esquema sujeito-objeto na aplicação e interpretação jurídica surge a teoria desenvolvida por Streck e denominada de Crítica Hermenêutica do Direito ou nova crítica do direito, sustentada especialmente na resposta correta, ou seja, adequada à Constituição.

Há que se notar que a Crítica Hermenêutica do Direito passa necessariamente pela compreensão e interpretação jurídicas, fundamentais para chegar-se à nova teoria da Constituição, traduzida em uma nova teoria 
das fontes, da norma e da interpretação.

A linguagem, conforme a época em que discutida, recebe interpretações variadas e torna-se essencial para a análise da aplicação e interpretação do direito. A percepção de que as coisas são independentes de palavras e o seu sentido advém de uma convenção humana é a síntese do convencionalismo, defendido pelos sofistas. (STRECK, 2011a, p. 151-160)

$\mathrm{Na}$ concepção platônica, a linguagem tinha apenas uma localização secundária, era instrumento, não sendo necessária para conhecer a realidade, que poderia ser conhecida pela sua essência, por sua natureza transcendental e não linguística. Na concepção aristotélica, as palavras tinham sentido, pois as coisas possuíam uma essência. Daí decorre a metafísica como ciência de fundamento para todas as outras. (STRECK, 2011 la, p. 151-160)

Posteriormente, com o nominalismo de Guilherme de Ockham, valoriza-se a linguagem - postura antimetafísica - diferenciando-se de Platão e Aristóteles, compreendendo que os universais destes eram apenas palavras e nomes, sem relação com os objetos. Para Ockham o que interessava era o passível de experimentação, considerando como única realidade, os indivíduos e objetos considerados apenas individualmente, ou seja, considerados como seres singulares (DE BONI, 2009, p. 615). Diz-se que o nominalismo foi o precursor para a viragem linguística que ocorreria mais tarde, no Século XX, não só pelo reconhecimento e importância que deu à linguagem, mas porque apostava na vontade, ou seja, possibilitando o surgimento da subjetividade que contrapõe a vontade individual àquilo dado na generalidade. (STRECK, 201 1a, p. 167)

Tal subjetividade é o esquema sujeito-objeto de forma que o sentido não está exclusivamente nas coisas, mas passa a ser dado conforme a consciência individualizada do sujeito - filosofia da consciência.

Streck (2011a, p. 187-188) ressalta que até o Século XIX pouca expressão de mudanças da filosofia da consciência para outro paradigma aconteceu. O expoente inicial da ruptura com a filosofia da consciência pode ser visto em Hamann, Herder e Humboldt, cada qual com suas posições, podendo-se destacar o último para quem a linguagem é visão de totalidade do mundo, não podendo ser entendidos dissociados, pois "a linguagem somente tem sua verdadeira existência no fato de que nela se apresenta (tem acesso) o mundo".

Também merecem destaque estudos de Pierce e Saussure, no início do século XX, pois trouxeram a análise da semiótica e da semiologia, incluindo a linguagem como parte destas, dando mais um passo no rompimento com a filosofia da consciência até então prevalecente e alcançando a viragem linguística. ${ }^{8}$

Com a viragem linguística, não há mais como compreender a linguagem como instrumento de comunicação e como exatidão e a essência das coisas, como determinantes de seu sentido. É o desenvolvimento da filosofia da linguagem - pragmática - que possibilita o rompimento com o neopositivismo - sintaxe e

${ }^{8}$ Neste sentido, indica-se a leitura do capítulo 8 da obra Hermenêutica Jurídica e(m) Crise de Lênio Luiz Streck. vol.09, no. 04, Rio de Janeiro, 2016.pp. 2421-2449 
semântica, sendo a própria linguagem a condição de possibilidade do filosofar. Não há assim, lugar para o sujeito solipsista. Há apenas lugar para o sentido que é dado pela linguagem, não pela consciência do seu intérprete. (STRECK, 2011a, p. 224)

O giro ontológico-linguístico explica-se em razão de que o "compreender é um existencial da própria condição humana, portanto, faz também parte da dimensão ontológica: é a questão do círculo hermenêuticoontológico", podendo-se então falar da ontologia que "trata do ser ligado ao operar fundamental do ser-aí (Dasein), que é o compreender do ser". (STRECK, 2011a, p. 225)

Discutindo a inovação na filosofia, Stein (2011, p. 63-64) reporta-se à Heidegger para tratar do círculo hermenêutico e reforça o papel da compreensão como paradigma pós-moderno para o a priori da filosofia quando destaca que "toda a interpretação é precedida por uma compreensão e somente podemos interpretar para compreender porque já compreendemos previamente nosso modo de ser no mundo”, restando a linguagem não como uma terceira coisa entre sujeito e objeto, mas como condição de possibilidade de manifestação de sentido. ${ }^{9}$

Complementa-se: "o fato de podermos dizer que algo é, já pressupõe que tenhamos dele uma compreensão, ainda que incerta e mediana. E mais! Só nos relacionamos com algo, agimos, direcionamos nossas vidas na medida em que temos uma compreensão do ser". Além disto, só há como compreender o ser quando já existe a compreensão prévia da faticidade e existência do Ser-aí, perguntando-se sobre o ente, pois "todo ente só é no seu ser".(STRECK, 2011a, p.240) Isto é o Círculo Hermenêutico e a diferença ontológica de Heidegger e explicado por Streck. ${ }^{10}$

Atribuir sentido às coisas não significa meramente reproduzir, mas produzir sentido, sendo a interpretação da lei efetivamente uma tarefa criativa. A aplicação hermenêutica (STRECK, 2013b, p. 93) não se faz por partes e a compreensão já é aplicar, não podendo ser concebida a cisão entre compreender e aplicar e a linguagem como algo que intermediariamente se põe.

Aqui, insere-se a Crítica Hermenêutica do Direito ou a Nova Crítica do Direito de Streck, afirmando que somente no ato aplicativo é que os sentidos irão manifestar-se, decorrendo isto da complementariedade das teorias da filosofia hermenêutica, hermenêutica filosófica e integrativa, para chegar-se a tese da resposta correta, adequada à Constituição.

Tal Crítica Hermenêutica, segundo o seu defensor, tem sentido na democracia e com a Constituição compromissória, isto é, demonstrando a necessidade de respeito ao texto constitucional no contexto de garantia e

\footnotetext{
${ }^{9}$ É interessante notar que Stein traduz a importância da compreensão para a inovação na filosofia pelo seguinte trecho: "Mesmo que pareça temerário, afirmar a importância desse novo paradigma hermenêutico soluciona uma série de questões não resolvidas na teoria do conhecimento e introduz algumas respostas, de há muito buscadas para pensarmos de modo adequado o que pode significar um a priori, ou mesmo o que pode simplificar os debates em torno dos problemas do fundamento da Filosofia atual".

${ }^{10}$ Para melhor compreensão do assunto, recomenda-se a leitura de Streck, 2011 a, em seu capítulo 10, quando aborda a viragem linguística e a interpretação do Direito em seu interior.
} 
efetivação de direitos e à democracia - representativa - o que se traduz na impossibilidade de decisões judiciais discricionárias.

Conforme já demonstrado anteriormente, o ativismo judicial acaba sendo a atuação dos juízes e tribunais extrapolando suas competências, no mais das vezes, como se fossem legisladores, acabando por interpretar e atribuir sentidos aos textos conforme sua própria subjetividade, ato de vontade discricionário, que viola as garantias constitucionais e a democracia.

O contexto brasileiro dá margem à postura ativista judicial, encontrando brechas na judicialização da política. A teoria da Crítica Hermenêutica do Direito busca assim, superar os paradigmas até então vigentes em especial pela aposta na superação da discricionariedade como fundamentadora da decisão judicial e no reforço da importância da Constituição.

Para chegar-se à tal resposta adequada alguns pressupostos devem ser cumpridos, quais sejam, a autonomia do direito, o controle da interpretação constitucional - a discricionariedade -, o respeito à coerência e integridade do direito, os quais passam a ser analisados na sequência.

A força normativa da Constituição representa aquilo que existe de mais avançado no tratamento dos direitos fundamentais e, em especial, à efetividade destes direitos. A ainda necessidade de uma Constituição dirigente e compromissória deixa nítida a problemática da ainda não concretização de direitos - promessas incumpridas da modernidade - conforme já ressaltado.

Um dos aspectos que permeiam a força normativa da Constituição e que está diretamente relacionado com o direito à resposta adequada à Constituição e, consequentemente, respeito à democracia é a autonomia do direito. Moral, política e economia são as principais dimensões que tem relação com o direito face à evolução social e à globalização, mas isto não pode abrir espaço para que a decisão judicial deixe de ser jurídica.

Destaca-se que Sausen (2013, p. 27-29), ao refletir sobre os influxos da política e da economia nas decisões judiciais, expõe que tais fatores não podem interferir de tal modo que assujeitem o direito levando-o a ser medido economicamente ou que as decisões judiciais possam favorecer alguns poucos em detrimento da população. Isto acaba sendo fator para a estandardização do direito, com o surgimento, por exemplo, das súmulas vinculantes que acabam por retirar do julgador a possibilidade de análise particularizada da demanda, decidindo-a no plano abstrato.

Em sua análise sobre Direito e Economia, Morais da Rosa (2012) ressalta que o direito transformou-se em instrumento econômico diante das exigências do neoliberalismo e isto acaba por reduzir o espaço da Constituição e dos direitos fundamentais que preconiza em nome da noção de eficiência, da economia, do custobenefício, do Mercado, sendo o Constitucionalismo Garantista uma resposta para tal situação, reforçando a autoridade da Constituição e da democracia. 
A autonomia é condição de possibilidade do próprio direito no sentido de que não passe a ser refém de outras dimensões, ou predadores externos. Como decorrência da autonomia, surgem os mecanismos de controle das decisões judiciais com o intuito de verificar se a decisão proferida teve base jurídica ou se aderiu às outras dimensões - caráter discricionário -, legitimando a indeterminabilidade do direito e, se isto acontecer, corre-se o risco do retorno à filosofia da consciência e ao pragmatismo político jurídico ${ }^{11}$. Então, com isto, reconhece-se que o direito foi atacado pelos predadores externos e pelos decisionismos judiciais. (STRECK, 2010)

Assim, a Constituição, enquanto direito que é produzido democraticamente deve ser o centro da decisão judicial, o que significa o reforço à autonomia do direito, de modo que este não se torne um instrumento da economia, da moral ou da política e possibilite decisões discricionárias, pois no momento em que a decisão judicial afasta-se da Constituição, os fundamentos podem ser os mais diversos, sendo literalmente escolhidos pelo julgador, acarretando isto em nítida violação constitucional e incidindo em ativismo judicial.

Outro ponto que merece destaque para ter-se uma resposta adequada à Constituição é o combate à discricionariedade judicial, o que não implica a proibição de interpretar, mas que a concretização do texto jurídico não pode ser fruto da vontade daquele que interpreta, pois se assim for, estar-se-á retornando ao esquema sujeitoobjeto e deixando-se a decisão judicial a cargo da subjetividade do intérprete.

Se a decisão não é escolha, mas se dá pela compreensão de algo que se antecipa, deve ser estruturada de acordo com o sentido daquilo que a comunidade política projeta, não havendo abertura para optar entre possibilidades de decidir. (STRECK, 2013, p. 107-108)

A importância de que a decisão esteja conforme a Constituição e não os juízos do julgador também é destacada por Perez-Luño, quando ao analisar a função de julgar no Estado Constitucional, faz uma análise sobre os juízes como criadores de direitos, dizendo que mesmo que a concepção de juiz boca da lei esteja superada, não dá azo para que possa dizer o que achar conveniente sobre algo, pois a sentença não pode estar à margem do ordenamento jurídico e conclui pela negação de que a decisão judicial possa ser arbitrária com a seguinte expressão: "Se os juízes tivessem esta faculdade, seria inútil a divisão de poderes, pois a arbitrariedade que se evita com ela no Rei, trasladaria-se aos juízes, e então no lugar de somente um déspota teríamos tantos déspotas como juízes".(CALVO, 2010, p. 100)

A discricionariedade acaba manifestando-se nitidamente na resolução dos chamados casos difíceis ( hard cases), sendo que para o positivismo, devem ser resolvidos pela delegação ao juiz da escolha decisória e, naquilo que se chama de pós-positivismo, deve-se resolver pela ponderação como modo para solucionar a colisão de princípios, o que nada mais é, deixar ao juiz a responsabilidade pela escolha do princípio aplicável ao caso,

11 "[...] o juiz pragmatista inova e produz direito novo, ainda que, para ele, o diálogo com a tradição e os princípios morais nela contidos seja menos relevante; o juiz pragmatista pode sempre se referir a argumentos e princípios que se encontram fora daquela tradição, sendo até mesmo estritamente instrumental, isto é, consequencialista, em suas ações. Para ambas as visões, no entanto, a vol.09, n. 04, Rio de Janeiro, 2016. pp. 2421-2449 2441 
acabando por incidir novamente em discricionariedade.(STRECK, 2012, p.231-235)

Também é este o entendimento de Tassinari (2013, p. 116), destacando que a superação da discricionariedade judicial é um dos desafios impostos ao Constitucionalismo Contemporâneo e de Trindade (2012, p. 131), reforçando a necessidade de mecanismos idôneos para controle da discricionariedade judicial, uma vez que a decisão judicial deve estar limitada pela lei e vinculada à Constituição.

Mas, não basta apenas reconhecer a autonomia do direito e o combate à discricionariedade como também, a necessidade de coerência e integridade como essenciais para encontrar-se a resposta adequada à Constituição.

Isto implica dizer que uma decisão coerente deverá ser aplicada em casos semelhantes, ou seja, que os princípios aplicados serão igualmente aplicados em casos que mantenham alguma semelhança e implicará na integridade do direito, rechaçando a arbitrariedade (STRECK, 2013b, p. 111). Mas o caso - que somente pode ser concreto - não pode receber a interpretação e aplicação do direito com base em uma análise abstrata e apenas jurídica, o que acabaria possibilitando múltiplas respostas, mas sim, deve ter uma análise fática, possibilitando a adequabilidade à Constituição.

Considerar a integridade na aplicação do direito significa levar em conta a história institucional do direito e interpretá-la conforme os princípios. Os juízes deveriam interpretar o direito criado por uma comunidade democrática-constitucional e, neste sentido, não interferir na decisão com seus julgamentos pessoais. Ainda, devem considerar o valor da tradição e do passado, aplicando o princípio de modo que esteja articulado com o passado e coerente com o futuro. (CHUERI; SAMPAIO, 2012, p. 177-197)

Também com base em Dworkin, é o posicionamento de Streck (2012, p. 281) que ressalta o seguinte: "o juiz deverá optar pela interpretação que, do ponto de vista da moral política, melhor reflita a estrutura das instituições e decisões da comunidade, [...] a que melhor represente o direito histórico e o direito vigente, sendo [...] assim, a resposta correta para o caso concreto".

E isto implica também a necessidade de que a decisão seja fundamentada - a fundamentação da fundamentação - não podendo o intérprete não imponha um conteúdo não jurídico, até mesmo porque o caso concreto é a síntese hermenêutica-interpretativa, superando o esquema sujeito-objeto e deve ser justificado juridicamente. (STRECK, 2012, p. 407)

Integridade é existencial; possibilita distinguir pré-juízos autênticos (verdadeiros) de pré-juízos inautênticos (falsos), sendo os pré-juízos a antecipação, a pré-compreensão não dominável, não sendo possível, por isto, a subsunção ou dedução. As proposições jurídicas são verdadeiras se derivam dos princípios da justiça, equidade e devido processo legal que oferecem a melhor interpretação à comunidade. (STRECK, 2012, 353-353)

autonomia do juz é parte constitutiva e essencial da sua atividade inovadora”. (EISENBERG, 2002, p. 43-61). 
Neste contexto podem ser analisadas as súmulas vinculantes, que não possibilitam ao julgador analisar as peculiaridades do caso concreto, senão, a mera aplicação do enunciado à determinada situação abstratamente posta. Embora tratando sobre as reformas legislativas, extrai-se de Sausen (2013, p. 40) o seguinte: "Os juízes [...] devem decidir livremente, tendo como limite a Constituição da República e a legislação a partir dela concebida e recepcionada via processo democrático, respeitando, por óbvio, a tradição, coerência e integridade do direito $[. .]$.

E, novamente utilizando-se do ensinamento de Streck (2012, p. 406), quanto à ligação da resposta correta com integridade e coerência:

A resposta correta é [...] a síntese hermenêutica [...] em que ocorre a fusão de horizontes. [...]. É onde se encontram integridade e coerência: a tradição filtrada/atravessada pela reconstrução linguística a partir do texto constitucional que representa o lócus privilegiado do acontecer da atividade do jurista [...] e a garantia de que o intérprete está comprometido com a intersubjetividade que o coloca no interior de uma cadeia de sentidos; por isso, ele não "dispõe" dos sentidos (essa questão talvez seja a mais difícil para o intérprete do direito, formado em uma tradição de cariz solipsista).

Então, para o encontro da resposta adequada é necessário que, na aplicação do direito e princípios seja respeitada a coerência entre as decisões, de forma que as decisões para casos semelhantes tenham a mesma aplicação e, que haja a integridade, ou seja, a reconstrução histórica dos casos julgados, de forma a considerar as decisões passadas e as futuras, com apoio da jurisprudência e da doutrina, não esquecendo que tudo isto só pode ocorrer ao analisar-se a faticidade do caso posto em decisão.

\section{CONSIDERAÇÕES FINAIS}

A abordagem realizada no presente trabalho buscou compreender o ativismo judicial no Brasil e sua apresentação diante do respeito à Constituição e à Democracia, buscando-se na Crítica Hermenêutica do Direito, os aportes necessários para a garantia de direitos e da não-violação do Estado Constitucional-Democrático de Direito.

Assim, desenvolveu-se o estudo em três contextos: democracia; ativismo judicial e Teoria Hermenêutica do Direito. Inicialmente, o modelo clássico de democracia permitia ao povo apenas escolher seu representante e este faria um governo "para o povo e pelo povo", não importando se os interesses do povo fossem realmente atendidos.

Quando este modelo representativo entrou em crise, principalmente por não mais conseguir dar conta das demandas da sociedade, percebeu-se a necessidade de uma democracia que realmente representasse os interesses do povo, surgindo então o modelo de democracia participativa, que também não foi suficiente para atender à vontade popular. 
Com a crise da representatividade e da participação popular, deslocou-se para outro polo a concretização dos direitos fundamentais previstos constitucionalmente, sendo o Poder Judiciário o lócus para tanto, já que a Constituição dirigente e compromissória ainda vive no Brasil, mas demanda um novo olhar, deixando de ser apenas texto para tornar-se realidade. E a concretização, quando feita descriteriosamente, acaba sendo a porta de entrada para o ativismo judicial.

Percebe-se que uma das grandes questões discutidas atualmente tem sido o ativismo judicial, assumindo os mais variados contornos e sentidos, conforme os partidários de uma ou outra teoria. Passa-se por uma compreensão do positivismo jurídico exegético, com o chamado juiz boca da lei até chegar-se ao pós-positivismo, termo entendido por muitos como neoconstitucionalismo e que representaria uma superação do positivismo com a aplicação dos princípios.

A evolução e mudança pregadas pelos adeptos do neoconstitucionalismo não pode ser aceita, uma vez que apenas repristina a atuação de juízes que agem deliberadamente por seus posicionamentos próprios, reforçando a filosofia da consciência, demonstrando que a arbitrariedade, associada à ponderação de princípios, está presente na solução de casos concretos, ignorando completamente conquistas insculpidas nos textos constitucionais e, além disto, violando frontalmente a democracia.

O juiz não pode simplesmente decidir da forma como quiser ou, conforme aquilo que acha correto. Deve decidir com base na Constituição e em princípios constitucionais aplicáveis para a questão, não havendo que se falar em ponderação de princípios, pois acabará sendo, nada mais do que uma escolha sua para qual princípio aplicar ao caso e, terminará reforçando o esquema sujeito-objeto, em que o sentido passa a ser dado conforme a consciência individualizada do sujeito intérprete - filosofia da consciência.

Com a viragem linguística, não há mais como compreender a linguagem como instrumento de comunicação e como exatidão e, a essência das coisas, como determinante de seu sentido. É o desenvolvimento da filosofia da linguagem - pragmática - que possibilita o rompimento com o neopositivismo - sintaxe e semântica, sendo a própria linguagem a condição de possibilidade da interpretação. Não há assim, lugar para o sujeito solipsista. Há apenas lugar para o sentido que é dado pela linguagem, não pela consciência do seu intérprete.

Portanto, com a superação da filosofia da consciência pela filosofia da linguagem, passa-se a analisar a compreensão como intrínseca ao sujeito e não mais como algo que servia apenas como instrumento para chegarse ao sentido do objeto. Já há uma pré-compreensão e a linguagem é a condição do ser no mundo, pois não se interpreta para compreender, ao inverso, compreende-se para depois interpretar, sendo a interpretação a explicitação do que foi previamente compreendido. (STRECK, 2013b, p.91)

Por isso, a abertura para a decisão ser proferida conforme a consciência do julgador acaba em discricionariedade, que é prejudicial para o direito construído democraticamente, pois a decisão judicial reclama vol.09, no. 04, Rio de Janeiro, 2016. pp. 2421-2449 2444 
uma adequação à Constituição, não podendo estar fundada em vontades pessoais do julgador que acabam por transbordar a sua competência e repristinar o paradigma sujeito-objeto na interpretação jurídica, impossibilitando que se chegue à uma resposta adequada à Constituição.

Para o encontro da resposta adequada à Constituição, utilizou-se a Teoria da Crítica Hermenêutica do Direito, de Streck, como referencial. Para tanto, traçaram-se alguns requisitos necessários, quais sejam, a autonomia do direito, o combate à discricionariedade, a integridade e a coerência.

Quanto à autonomia, impõe-se que o Direito não esteja submetido à outros campos como Economia, Moral, Política e que as decisões judiciais proferidas sejam de caráter jurídico. Imbricado com a autonomia está o combate à discricionariedade do intérprete, pois este não deverá escolher qual a melhor resposta ou qual princípio aplicar ao caso concreto posto em julgamento, mas decidir de forma a respeitar os princípios e a força normativa da Constituição, afastando-se de juízos pessoais e valorativos, que não devem estar presentes na decisão judicial.

Além disto, é possível verificar que a resposta adequada à Constituição também é aquela que respeita a coerência e a integridade do direito, ou seja, que os princípios serão igualmente aplicados em casos que mantenham semelhança a outros e, que o direito deverá ser analisado e aplicado como um todo, caso a caso, prezando pela faticidade, considerando a história institucional do direito e, possibilitando então, a adequabilidade à Constituição.

Assim, respeitados os requisitos expostos, é possível chegar a uma resposta adequada à Constituição e mais do que isto, respeitar a democracia, uma vez que a produção e criação do direito deverá ser feita apenas por quem tem competência para tanto, ou seja, o legislador e ao juiz, apenas caberá a interpretação que se manifesta na applicatioe advém da compreensão, não havendo, por oportuno, que falar-se em cisão do ato interpretativo.

Significa, assim, que a decisão judicial deverá ser fundamentada com argumentos de princípios e não argumentos políticos e que o juiz, ao ver o caso a solucionar, deverá decidir e não escolher a melhor decisão ou aquela que entender mais conveniente para o caso, pois não há mais espaço para falar-se em sujeito solipsista que, discricionariamente, acredita que decide - mas escolhe.

Portanto, a Constituição é o referencial de validade da ordem jurídica e deve ser nela que a decisão judicial deve estar fundamentada, afastando-se discricionariedades do intérprete e o ativismo judicial, sendo assim, condição de possibilidade para a concretização dos direitos fundamentais e respeito à democracia. 


\title{
CRITICAL HERMENEUTICS LAW AS GUARANTEED TO DEMOCRACY AND RESPECT TO THE CONSTITUTION FRONT JUDICIAL ACTIVISM
}

\begin{abstract}
The Federal Constitution of 1988 is essential milestone in the guarantee of rights and their implementation through the instruments listed in the constitutional text, also serving as the foundation of democratic rule of law. Because of the constant need to carry out the planned rights, the judiciary ends up becoming one of the vectors for both and sometimes just extrapolating the limits that could be revealed. Herein lies the present discussion, namely, the problem of respect for democracy ahead to judicial activism. To develop the study is used the deductive method. Initially it presents a historical approach on democracy and its relationship with the constitutional jurisdiction. Following builds a conceptual overview of the judicial activism and the factors that involve throwing yourself the question: "how to establish controls the interpretation of the law and prevent judges to take hold of the democratically constructed legislation?". To answer this question and answer to the problem proposed, uses the analysis Theory Hermeneutics Law Review, produced by Lenio Streck, being able to finally conclude that arises as a new paradigm in the interpretation of law, respecting democracy and showing overcoming of judicial activism, particularly by building an adequate response to the Constitution.
\end{abstract}

Keywords: Judicial Activism. Democracy. Critical Hermeneutics of Law.

\section{REFERENCIAS}

AGRA, Walber de Moura. Curso de Direito Constitucional. 7. ed. Rio de Janeiro: Forense, 2012.

BARROSO, Luís Roberto. Interpretação e aplicação da Constituição: fundamentos de uma dogmática constitucional transformadora. 7. ed. rev. São Paulo: Saraiva, 2009.

Neoconstitucionalismo e Constitucionalização do direito (O triunfo tardio do direito constitucional brasileiro), p. 15 . Disponível em: http://www.luisrobertobarroso.com.br/wpcontent/themes/LRB/pdf/neoconstitucionalismo_e_constitucionalizacao_do_direito_pt.pdf. Acesso em 22. jul. 2013

BARZOTTO, Luiz Fernando. O positivismo jurídico contemporâneo: uma introdução a Kelsen, Ross e Hart. São Leopoldo: Editora da Unisinos, 2007, v. 1.

BERCOVICI, Gilberto. Ainda faz sentido a Constituição Dirigente?. In: Revista do Instituto de Hermenêutica Jurídica do Rio Grande do Sul, v. 01, n. 06. Porto Alegre: Instituto de Hermenêutica Jurídica, 2008.

BOBBIO, Norberto. O futuro da democracia. 7. ed. Rio de Janeiro: Paz e Terra, 2000.

BONAVIDES, Paulo. Teoria Constitucional da Democracia Participativa: Por um Direito Constitucional de luta e resistência; Por uma Nova Hermenêutica; Por uma repolitização da legitimidade. 2. ed. São Paulo: Malheiros, 2003.

BRASIL. Constituição (1988). Constituição da República Federativa do Brasil. Brasilia, DF: Senado Federal, 1988. 
BULOS, Uadi Lammêgo. Curso de Direito Constitucional. 5. ed. rev. e atual. de acordo com a Emenda Constitucional n. 64/2010. São Paulo: Saraiva, 2010.

CALVO, J. Catecismo político, arreglado a la Constituición de la Monarquía española. Málaga: Facultad de Derecho de la Universidad de Málaga, 1992.

CITTADINO, Gisele. Judicialização da Política, Constitucionalismo Democrático e Separação dos poderes. In: VIANA, Luiz Werneck. A Democracia e os Três Poderes no Brasil. Belo Horizonte: UFMG, 2002.

CHUEIRI, Vera Karam de; SAMPAIO, Joanna Maria de Araújo. Coerência, integridade e decisões judiciais. Revista do Programa de Pós-Graduação em Direito da UFC. 2012, p. 177-197.

DE BONI, Luis Alberto. Guilherme de Ockham. In.: BARRETTO, Vicente de Paulo. (Coord). Dicionário de Filosofia do Direito. São Leopoldo: Editora Unisinos; Rio de Janeiro: Editora Renovar, 2009.

EISENBERG, José. Pragmatismo, direito reflexivo e judicialização da política. In.: VIANA, Luiz Werneck. A democracia e os Três Poderes no Brasil. Belo Horizonte: UFMG, 2002, p. 43-61.

FERRAJOLI, Luigi. Constitucionalismo principialista e constitucionalismo garantista. Trad. André Karam Trindade. In. FERRAJOLI, Luigi; STRECK, Lenio Luiz; TRINDADE, André Karam. (Org). Garantismo, hermenêutica e (neo) constitucionalismo. Porto Alegre: Livraria do Advogado, 2012.

FERREIRA FILHO, Manoel Gonçalves. Aspectos do Direito Constitucional contemporâneo. São Paulo: Saraiva, 2003.

MARSHALL, Willian P. Conservatism and the Seven Signs of Judicial Activism. University of Colorado Law Review, Chapel Hill, n. 73, p. 101-140, 2002.

MENDES, Gilmar. A jurisdição constitucional no Brasil e o seu significado para liberdade e a igualdade. Disponível em: http://www.stf.jus.br/arquivo/cms/noticiaartigodiscurso/anexo/munster_port.pdf. Acesso em 23 jul. 2013.

MORAIS DA ROSA, Alexandre. Constitucionalismo garantista: notas lógicas. In. FERRAJOLI, Luigi; STRECK, Lenio Luiz; TRINDADE, André Karam. (Org). Garantismo, hermenêutica e (neo) constitucionalismo. Porto Alegre: Livraria do Advogado, 2012.

NOJIRI, Sergio. Neoconstitucionalismo versus democracia: um olhar positivista. Curitiba: Juruá, 2012.

OLIVEIRA, Fábio Corrêa Souza de. Morte e Vida da Constituição Dirigente. Rio de Janeiro: Lumen Juris, 2010.

OLIVEIRA, Rafael Tomaz de. A Jurisprudência e a dicotomia público versus privado. Consultor Jurídico. CONJUR. Disponível em: http://www.conjur.com.br/2013-abr-06/diario-classe-jurisprudencia-dicotomiapublico-vs-privada. Acesso em 23 jul. 2013.

O conceito de princípio entre a otimização e a resposta correta: aproximações sobre o problema da fundamentação e da discricionariedade das decisões judiciais a partir da fenomenologia hermenêutica. Dissertação (Mestrado). Universidade do Vale do Rio dos Sinos - Unisinos. Programa de Pós-Graduação em Direito, São Leopoldo, RS, 2007.

PÉREZ LUNO, Antonio Enrique. Perspectivas e tendências atuais do Estado Constitucional. Tradução Jose Luis Bolzan de Morais, Valéria Ribas do Nascimento. Porto Alegre: Livraria do Advogado, 2012. 
ROCHA, Luiz Alberto Gurjão Sampaio. Estado, democracia e globalização. Rio de Janeiro: Forense, 2008.

SABINO, Marco Antonio da Costa. Quando o Judiciário ultrapassa seus limites constitucionais e institucionais. O caso da saúde. In.: GRINOVER, Ada Pellegrini; WATANABE, Kazuo. (coords). O controle jurisdicional de políticas públicas. 2. ed. Rio de Janeiro: Forense, 2013.

SADEK, Maria Tereza. Judiciário e Arena Pública: um olhar a partir da ciência política. In.: GRINOVER, Ada Pellegrini; WATANABE, Kazuo. (coords). O controle jurisdicional de políticas públicas. 2. ed. Rio de Janeiro: Forense, 2013.

SARLET, Ingo Wolfgang. A eficácia dos direitos fundamentais: uma teoria geral dos direitos fundamentais na perspectiva constitucional. 11. ed. rev. atual. Porto Alegre: Livraria do Advogado, 2012.

SARMENTO, Daniel. O neoconstitucionalismo no Brasil: riscos e possibilidades. In.:LEITE, George Salomão; SARLET, Ingo Wolfang. (Coord). Direitos fundamentais e estado constitucional: estudos em homenagem a J.J. Gomes Canotilho. São Paulo: Revista dos Tribunais; Coimbra: Coimbra Editora, 2009.

SAUSEN, Dalton. Súmulas, repercussão geral e recursos repetitivos: crítica à estandardização do Direito e resgate hermenêutico. Porto Alegre: Livraria do Advogado, 2013.

STEIN, Ernildo. Inovação na Filosofia. Ijuí: Ed. Unijuí, 2011.

STRECK, Lenio Luiz. Jurisdição constitucional e hermenêutica: uma nova crítica do Direito. Porto Alegre: Livraria do Advogado, 2002.

et. al. Estudos sobre (neo) constitucionalismo. São Leopoldo: Oikos, 2009.

Aplicar a "letra da lei" é uma atitude positivista? In.: Revista Novos Estudos Jurídicos - Eletrônica. v. 15, n.

1.p. 158-173, jan-abr 2010.

Hermenêutica Jurídica e(m) crise. 10. ed. Porto Alegre: Livraria do Advogado, 2011 a.

Contra o neoconstitucionalismo. Constituição, Economia e Desenvolvimento: Revista da Academia Brasileira de Direito Constitucional. Curitiba, 201 lb, n. 4, jan - jun, p. 9-27.

2012.

Verdade e Consenso: constituição, hermenêutica e teorias discursivas. 4 ed. 2. tiragem. São Paulo: Saraiva,

BOLZAN DE MORAIS, José Luiz. Ciência Política e teoria do estado. 7. ed., 2. tir. Porto Alegre: livraria do Advogado, 2012.

Democracia, Jurisdição Constitucional e Presidencialismo de Coalização. In.: Observatório da Jurisdição Constitucional. Instituto de Direito Brasiliense: Brasília. Ano 6, v. 1, mai/2013a. $2013 b$.

$\mathrm{O}$ que é isto - decido conforme minha consciência? - .4 ed. rev. Porto Alegre: Livraria do Advogado,

O velho travestido de novo e o moralismo do Faustão, disponível em: http:/ /www.conjur.com.br/2013jun-27/senso-incomum-velho-travestido-moralismo-faustao. Acesso em 20 jul. 2013.

TASSINARI, Clarissa. Jurisdição e ativismo judicial: limites da atuação do judiciário. Porto Alegre: Livraria do Advogado, 2013.

TAVARES, André Ramos. Tribunal e Jurisdição Constitucional. São Paulo: Instituto Brasileiro de Direito Constitucional, 1998. 
TEIXEIRA, Anderson Vichinkeski. Ativismo judicial: nos limites entre racionalidade jurídica e decisão política. Revista Direito GV, São Paulo, v. 8, n. 1, June 2012. Disponível em: $<$ http://www.scielo.br/scielo.php?script=sci_arttext\&pid=S1808-24322012000100002\&lng=en\&nrm=iso>. Acesso em 18 jul 2013.

TRINDADE, André Karam. Garantismo versus neoconstitucionalismo: os desafios do protagonismo judicial em terrae brasilis. In. FERRAJOLI, Luigi; STRECK, Lenio Luiz; TRINDADE, André Karam. (Org). Garantismo, hermenêutica e (neo) constitucionalismo. Porto Alegre: Livraria do Advogado, 2012.

Trabalho enviado em 13 de março de 2016.

Aceito em 07 de maio de 2016. 